\title{
A Hans Krüger Arctic Expedition Cache on Axel Heiberg Island, Nunavut
}

\author{
ROBERT W. PARK ${ }^{1}$ and DOUGLAS R. STENTON ${ }^{2}$
}

(Received 13 June 2006; accepted in revised form 31 July 2006)

\begin{abstract}
In 1999 a team of geologists discovered an archaeological site near Cape Southwest, Axel Heiberg Island. On the basis of its location and the analysis of two artifacts removed from the site, the discoverers concluded that it was a hastily abandoned campsite created by Hans Krüger's German Arctic Expedition, which was believed to have disappeared between Meighen and Amund Ringnes islands in 1930. If the attribution to Krüger were correct, the existence of this site would demonstrate that the expedition got farther on its return journey to Bache Peninsula than previously believed. An archaeological investigation of the site by the Government of Nunavut in 2004 confirmed its tentative attribution to the German Arctic Expedition but suggested that it is not a campsite, but the remains of a deliberately and carefully constructed cache. The finds suggest that one of the three members of the expedition may have perished before reaching Axel Heiberg Island, and that the survivors, in order to lighten their sledge, transported valued but heavy items (including Krüger's geological specimens) to this prominent and well-known location to cache them, intending to return and recover them at some later date.
\end{abstract}

Key words: German Arctic Expedition, Hans Krüger, archaeology, geology, Axel Heiberg Island, Nunavut

RÉSUMÉ. En 1999, une équipe de géologues a découvert un lieu d'importance archéologique près du cap Southwest, sur l'île Axel Heiberg. En fonction de l'emplacement découvert et de l'examen de deux artefacts de ce lieu, on a conclu qu'il s'agissait d'un campement abandonné rapidement par l'expédition allemande de l'Arctique de Hans Krüger, qui aurait disparu entre les îles Meighen et Amund Ringnes en 1930. Advenant que l'attribution à l'expédition de Krüger soit exacte, l'existence de ce lieu montrerait que l'expédition serait allée plus loin qu'on ne l'avait cru lors de son voyage de retour à la péninsule Bache. Grâce à des fouilles réalisées par le gouvernement du Nunavut en 2004, on a pu confirmer provisoirement l'existence de ce lieu et l'attribuer à cette expédition allemande de l'Arctique, tout en laissant supposer qu'il ne s'agit pas d'un campement mais plutôt des restes d'une cache construite avec soin. Les découvertes laissent croire que l'un des trois membres de l'expédition aurait péri avant d'arriver à l'île Axel Heiberg, et que les survivants, dans le but d'alléger leur charge, auraient transporté des objets précieux, mais lourds (dont les spécimens géologiques de Krüger) à cet endroit important et bien connu pour les y cacher, ayant l'intention de revenir les récupérer plus tard.

Mots clés : expédition allemande de l’Arctique, Hans Krüger, archéologie, géologie, île Axel Heiberg, Nunavut

Traduit pour la revue Arctic par Nicole Giguère.

\section{INTRODUCTION}

On 19 March 1930, five men set out westward across Ellesmere Island from the Royal Canadian Mounted Police (RCMP) post located on Bache Peninsula (Fig. 1). This was the German Arctic Expedition, led by geologist Hans Krüger. Its stated goal was to map a specific geological formation known from both West Greenland and Ellesmere Island, although Krüger may also have had much more ambitious goals (de Laguna, 1997). As noted by William Barr (1993) in his definitive account of the expedition and its aftermath, Krüger was accompanied by Åge Rose Bjare, a Dane, Akqioq, a Polar Inuk, and for the first weeks of the trip, by two other Polar Inuit transporting additional supplies. Upon reaching Depot Point in Eureka Sound, the depleted supplies from the main sledge were replaced and, as planned, the two supply sledges then returned to Bache Peninsula with some excess equipment and the expedition's first geological samples. Krüger, Bjare, and Akqioq continued westward with the remaining sledge, following a course along Eureka Sound and Nansen Sound toward the northern tip of Axel Heiberg Island. The two Inuit who brought back their supply sledges provided the last eyewitness account of the expedition. They reported to a member of the RCMP that when they left Krüger, Bjare, and Akqioq,

with only one komitik and fifteen dogs, Krueger's komitik was then so heavily loaded that the team and men could hardly move it... The load consisted chiefly of pemmican for men and dogs, a quantity of tea, one case of ammunition, two rifles, three cans of coal oil (about 15 gallons), primus

\footnotetext{
${ }^{1}$ Department of Anthropology, University of Waterloo, Waterloo, Ontario N2L 3G1, Canada; rwpark@uwaterloo.ca

${ }^{2}$ Government of Nunavut Department of Culture, Language, Elders \& Youth, P.O. Box 1000, Station 800, Iqaluit, Nunavut X0A 0H0, Canada; dstenton1@gov.nu.ca

(C) The Arctic Institute of North America
} 


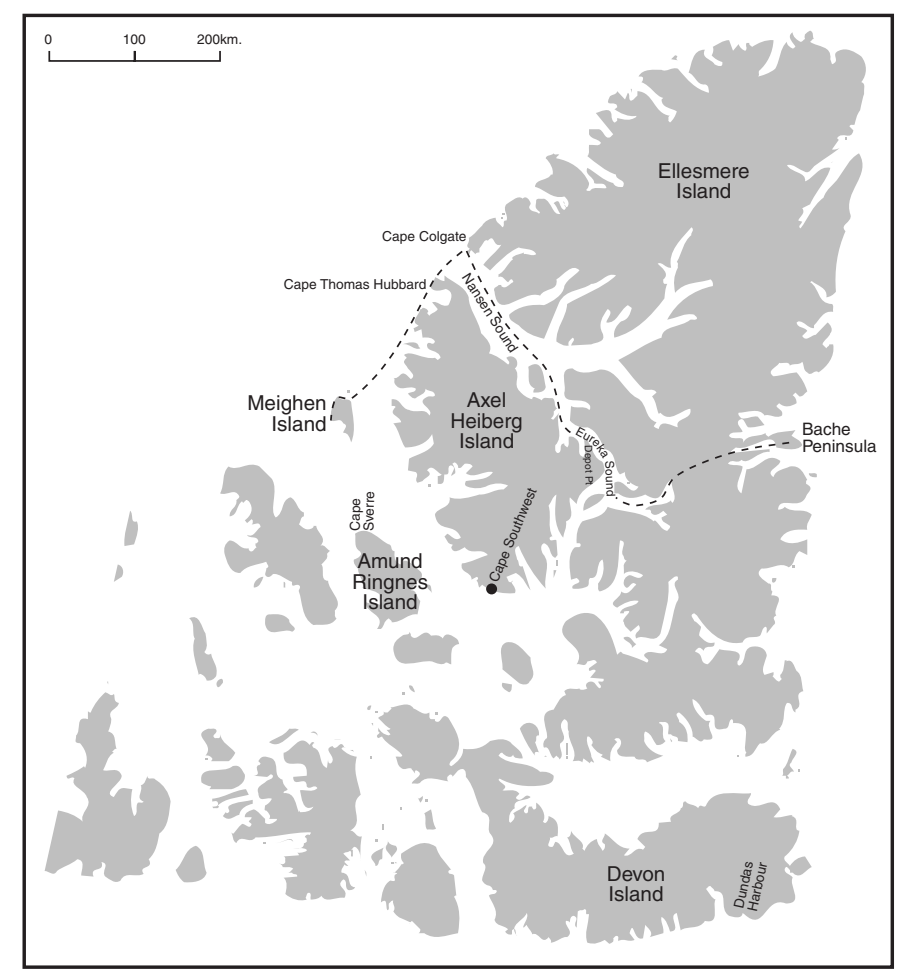

FIG. 1. Map of High Arctic Nunavut, showing the location of Cape Southwest and the known route of Hans Krüger's 1930 expedition from Bache Peninsula to Meighen Island. Redrawn after information in Barr (1993) and de Laguna (1997).

lamps, deerskin sleeping bags, clothing, camp equipment, double tent, snow-shoes, skis, heavy scientific equipment, a deep sea sounding wire (very heavy), and other miscellaneous equipment. (Joy, 1931, as cited in Barr 1993:289)

The failure of Krüger's expedition to return that year to Bache Peninsula or to another base at Dundas Harbour on Devon Island prompted the RCMP to mount a search patrol in the spring of 1931, but poor snow conditions prevented them from reaching Axel Heiberg Island. Concern deepened considerably through that year with the continued absence of the three explorers and in the spring of 1932, the RCMP mounted several very extensive and difficult search patrols. These efforts, which included circumnavigation of Axel Heiberg Island and part of Devon Island, produced only one sign of the party: a note left by Krüger at Cape Thomas Hubbard at the north end of Axel Heiberg Island. The note, dated 24 April 1930, stated Krüger's intention to travel from Axel Heiberg Island to Meighen Island, but the RCMP patrol was prevented from investigating Meighen Island by poor ice conditions and a lack of food for their dogs (Barr, 2004:151).

The note found by the RCMP demonstrated that Krüger had been following the standard practice of Arctic explorers of leaving notes in cairns at prominent locations along their routes. The fact that they did not find any other notes, despite scrutinizing prominent landforms and well-known locations where previous explorers had left records, such as Axel Heiberg's Cape Southwest, convinced the RCMP that Krüger's expedition had not returned from Meighen Island-if indeed they had reached it. On the basis of the poor ice conditions observed during their search patrols in 1932 and the extreme difficulties encountered in finding enough food for their dogs, the RCMP concluded that Krüger and his companions had probably starved to death during the winter of 1930-31 (Barr, 1993).

In the 1950s, two other notes deposited by Krüger's expedition were found during the course of geological research activities. The first was found in 1954 near Cape Colgate at the mouth of Nansen Sound, the northwesternmost point of Ellesmere Island. This message was written on 22 April 1930, two days before the Cape Thomas Hubbard note. The second, dated 6 May 1930, was found in 1957 at the southwestern corner of Meighen Island. This note confirmed that Krüger and his companions had safely reached Meighen Island, and it identified Cape Sverre on Amund Ringnes Island as their next destination. A search of Amund Ringnes Island in 1958 failed to produce any further notes or other evidence of Krüger's expedition, leading many researchers to conclude that Krüger and his companions must have perished somewhere out on the sea ice between Meighen Island and Amund Ringnes Island. Plausible scenarios included the loss of their sledge by plunging through thin ice, resulting in their death from exposure or starvation, or the death of all three men in their sleep inside a too-tightly sealed tent or snow house as a result of carbon monoxide poisoning from a faulty stove (Barr, 1993).

Not everyone was convinced that Krüger's party had perished on the ice between Meighen and Amund Ringnes islands. Barr (1993:300-301, 2004:167) quotes Harry Stallworthy, who led one of the RCMP sledge searches in 1932, and Geoffrey Hattersley-Smith, a geologist who later did considerable fieldwork in the region, as being convinced that someday a "last camp" of the German Arctic Expedition might be found. In a response to Barr's (1993) article, Osczevski (1994) expressed the same hope, and indeed enthusiasts have continued to search for any additional evidence of the lost expedition (e.g., Kobalenko, 2002:173-187). However, despite substantial geological and other research activity in the region, no further traces of Krüger and his team were reported for more than four decades after the discovery of the Meighen Island note.

\section{THE SbJk-1 SITE}

In July 1999, a team of geologists working on Axel Heiberg Island observed a small cluster of objects on the inland slope of a sandy beach ridge near Cape Southwest (Brooks et al., 2004). Investigation of the site revealed an intriguing assemblage of historic-era items that included a transit and compass, an enameled cup and plate, a heavy galvanized fuel canister, a food can, canvas fragments, and a piece of clothing with wooden buttons and a "label of 


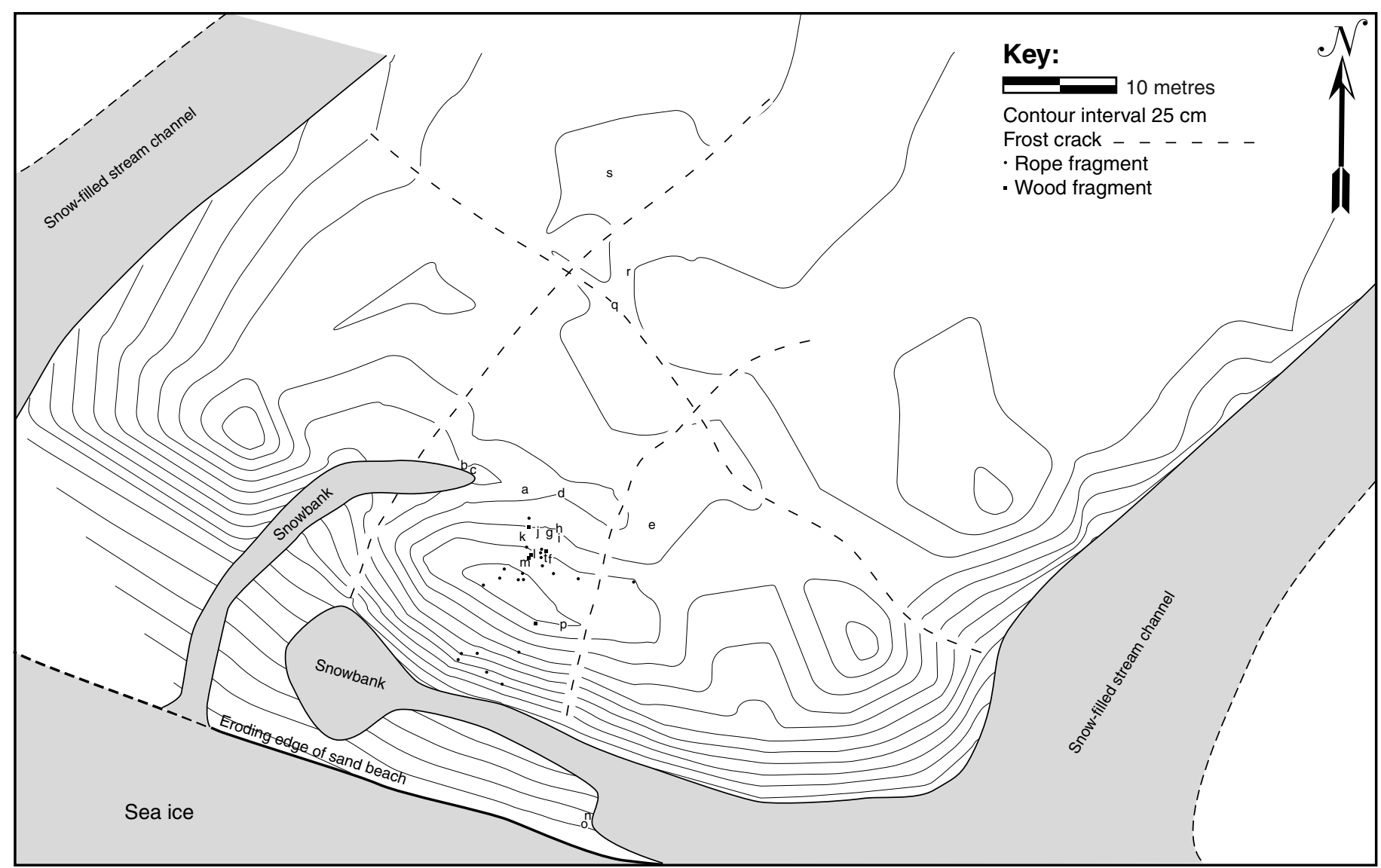

FIG. 2. Contour map of site SbJk-1 showing the location of the finds with respect to the topography and to the snowbanks as they existed at the end of June 2004. The letters identify the diagnostic finds and their locations: a. Transit; b. Wooden box with leather hinge straps; $c$. Canvas fragment; d. Enameled cup; e. Clothing fragment with two buttons; f. Geological rock specimen; g. Enameled plate; h. Can containing 26 geological rock specimens; i. Galvanized fuel can; j. Wood fragment with two screws; $k$. Wooden box part; 1. Funnel; $m$. Scatter of 65 geological rock specimens; $n$. Wooden box lid with hinges; o. Canvas fragment; $p$. Button; q. Canvas with grommet and rope; r. Canvas fragment; s. Sleeve from a sweater; t. Button.

German origin" (Brooks et al., 2004:225). They also reported observing "printed material" that was "protruding through the surface sand" and a number of geological samples. Assessing the possible importance of the discovery, the researchers decided to remove the transit and compass "for preservation and identification." The items were sent to the Canada Science and Technology Museum in Ottawa, where investigation revealed that the transit was of German manufacture and would have been purchased between 1921 and 1925 (Brooks et al., 2004). That information, plus a review of the explorers and researchers known to have traveled in that part of the Arctic, suggested that the discovery was a campsite that had been briefly occupied by Krüger's 1930 German Arctic Expedition. Cape Southwest and other prominent landforms on southern Axel Heiberg Island would presumably have been on their return route to Bache Peninsula from Amund Ringnes Island or Meighen Island (Brooks et al., 2004). If this inference were correct, the site would be a significant discovery, as it would demonstrate irrefutably that the entire team did not perish out on the ice after departing Meighen Island, and that their sledge must not have been lost through the ice before they reached the Cape Southwest area.
The Government of Nunavut was first informed of the 1999 discovery in May 2003. The information that was submitted indicated that the archaeological site was potentially significant and that artifacts requiring intervention (e.g., the clothing and printed materials) were exposed on the surface of the site. Further, Brooks et al. (2004) had made a strong case for their attribution of the site to the German Arctic Expedition, but proper documentation and assessment of the site were needed to confirm the connection to Krüger and possibly shed new light on the fate of his expedition. Accordingly, the authors investigated the site (SbJk-1) for the Government of Nunavut in late June 2004. The planned on-site assistance of a conservator from the Canadian Conservation Institute in Ottawa unfortunately had to be cancelled at the last minute; however, the Institute provided advice via satellite telephone during the excavation, as well as conservation services for the recovered artifacts afterwards.

Standard archaeological procedures were employed in the investigation of the site. The surface of the site area was carefully examined, all finds were flagged, and measurements for a site contour map (Fig. 2) and the positions of all specimens were recorded using a Total Station. Interestingly, it was found that some artifacts (e.g., the 


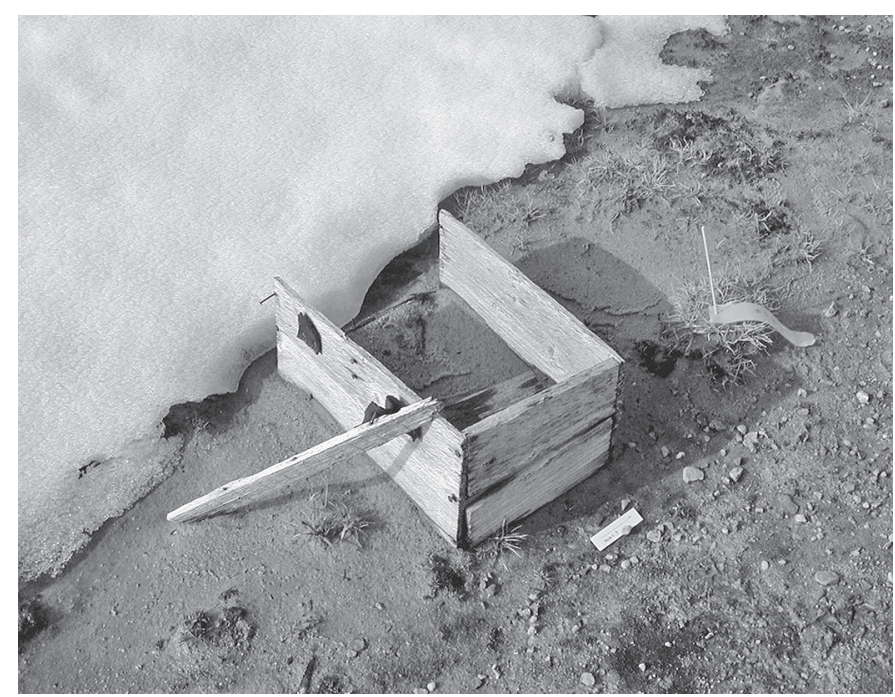

FIG. 3. Wooden box with leather hinges (SbJk-1:3).

food can) were not in the locations shown in the photograph taken in 1999 (Brooks et al., 2004:225), although there was no evidence that anyone had visited the site since that time. All surface finds were collected; however, because the duration of human activity at the site was thought to have been relatively brief and to have occurred at a time when the ground was frozen, only limited excavations were undertaken to free portions of several artifacts partially covered by a thin layer of windblown sand (e.g., pieces of fabric) and to recover a small number of geological samples that apparently had been pushed into the soft sand by the weight of overlying rock specimens. Apart from a few fragments of poorly preserved paper found on the underside of several of the buried rocks (showing that some or all of the rock samples had originally been wrapped in paper), the excavations revealed no evidence of subsurface cultural deposits.

With the exception of the geological samples, which are undergoing analysis at the University of Waterloo, the artifact assemblage recovered from SbJk-1 in 2004 is currently at the Canadian Conservation Institute for assessment and treatment. The assemblage includes the items described by the site's original discoverers as well as other items that presumably were covered by snow when the site was visited in 1999. These include a partial wooden box, a small wooden box lid, and another box part, all apparently from different boxes. The small box lid, which measures approximately $10 \mathrm{~cm}$ square, has two recesses in its inner surface and appears to be from a box designed to hold some piece of specialized equipment. The partial larger wooden box (Fig. 3) may have held the geological samples. Also found was a small metal funnel, probably used with the fuel can to fill the stove. Five separate pieces of canvas were found, one with grommets and rope attached and tentatively identified as a duffle bag. At least one of the other pieces of canvas was of a much heavier gauge, indicating that more than one canvas item is represented. Numerous fragments of rope of different thick-

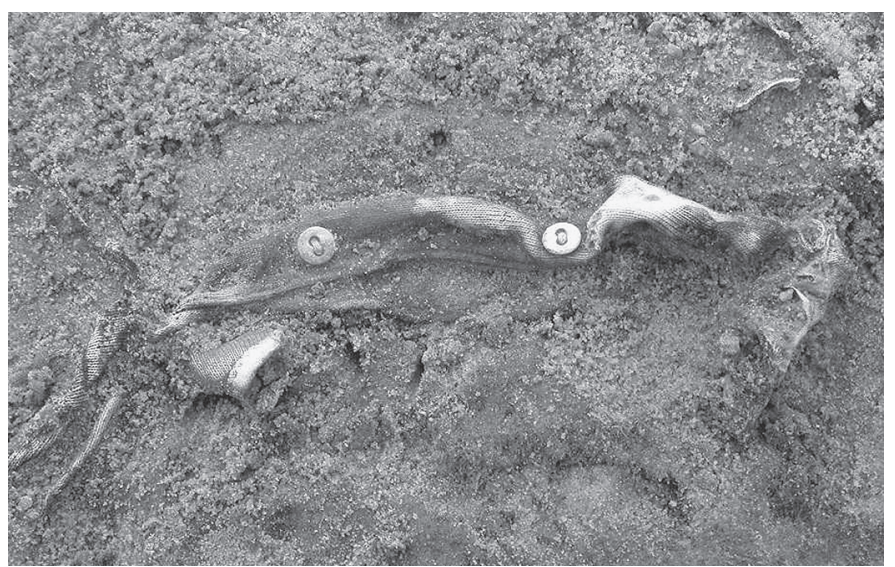

FIG. 4. Garment fragment, possibly underwear, with buttons (SbJk-1:6).

nesses were also found. One piece of fabric was found melting out of a partly frozen stream approximately $200 \mathrm{~m}$ from the central part of the site. At least two items of clothing were recovered, both in very fragmentary condition. One is the sleeve from a knit sweater and the other a piece of clothing with two buttons that appears to be from a combination suit of underwear (Fig. 4). This is almost certainly the "shirt (or long underwear) with label of German origin" and described as having wooden buttons (Brooks et al., 2004:225). However, by 2004 no evidence of a collar or label could be found. Two isolated buttons of a different design (and therefore presumably from a different garment) were also recovered. As was the case for the German clothing label, a thorough search for the "printed material" observed at the site in 1999 (Brooks et al., 2004:225) was unsuccessful. We conclude that both of these important artifacts were probably lost to the effects of the wind and blowing sand sometime between 1999 and 2004.

The large 'food' can (Fig. 5) is of the general type that is used to contain dry products such as baking powder. Its pry-out lid was still in place, and this is probably what led Brooks et al. (2004:225) to speculate that it was "an unopened tin of food." However, when the can was opened at the Canadian Conservation Institute, it was found to contain not food but 26 geological specimens. Each rock sample was wrapped in paper and within this wrapping most of the specimens were accompanied by a separate folded slip of paper. Written on each of the slips opened thus far are a specimen number, a date, and the location where the sample was collected. Comparison of the handwriting on the specimen labels with published copies of the German Arctic Expedition cairn notes (e.g., Barr, 1993) has confirmed that Krüger wrote the labels. Although the can was largely intact, the notes are in very fragile condition because the can had rusted through in several spots and exposed the contents to the elements. The notes and the geological specimens will be the subject of a separate publication exploring what they can tell us about the route taken by the expedition and what they might reveal about Krüger's geological research. 


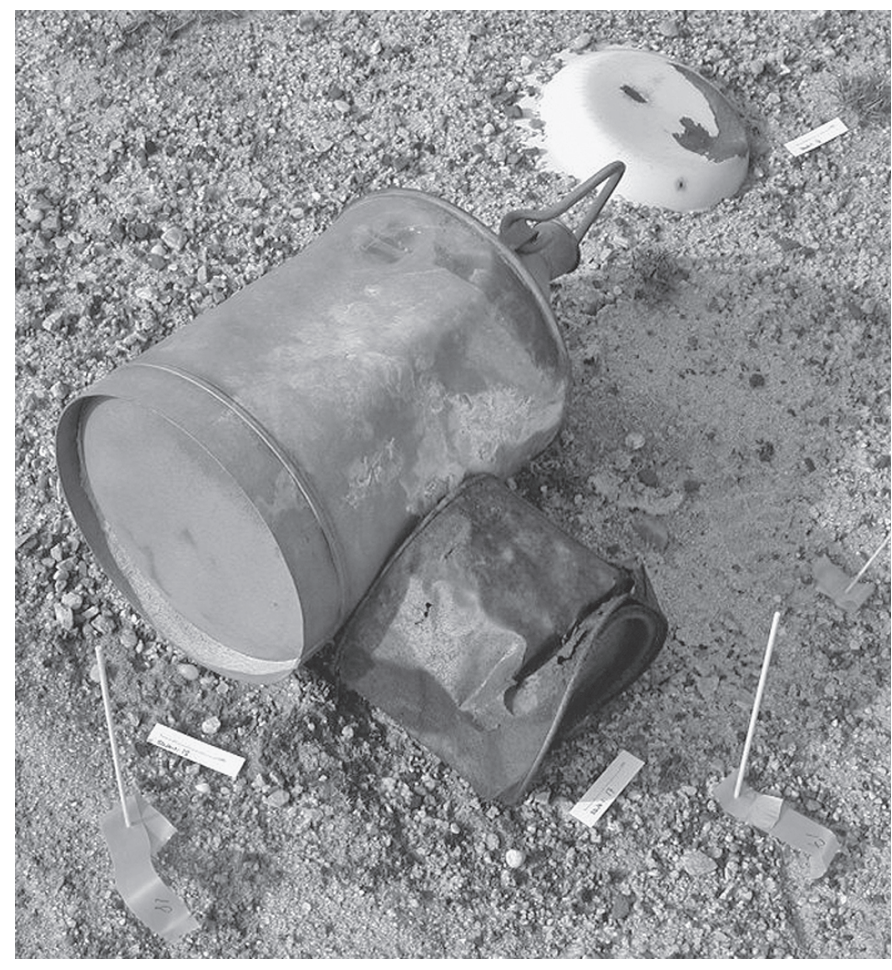

FIG. 5. The galvanized fuel container (SbJk-1:18), rusty food can containing geological specimens (SbJk-1:17), and partially buried enameled plate (SbJk16) as found in 2004.

\section{DISCUSSION}

Our discovery of the dated geological sample labels in Krüger's handwriting confirms Brooks et al.'s (2004) provisional conclusion that these finds derive from the German Arctic Expedition. However, our analysis of the site has led us to a different interpretation about the circumstances through which it was created. In their assessment of the site and its contents, referring to the transit and especially the geological specimens, Brooks et al. (2004:228) ask, "Why would one abandon such easily transported and important possessions that would constitute the very heart of the scientific expedition?" They offer the following possible scenario to account for this site:

The overriding impression that one is left with at this sparse site is its abandonment under duress. The fact that so few provisions remained, and that the tent itself may have been destroyed, suggests that the camp may have suffered a late spring snowstorm that buried what remained, and the explorers had no time or energy left to excavate it before escaping eastward.

Our findings are not consistent with this scenario. The idea that the expedition left behind any provisions at all appears to have been based on the presence of the closed food can. However, as noted, this actually contained geological specimens, not food. In addition, the identifiable pieces of canvas appear to have come from one or more bags; there is no indication that any derive from a tent. Thus, we interpret the assemblage not as the remains of an abandoned campsite, but as the remains of a cache, deliberately and carefully constructed on a slightly elevated spot approximately $5 \mathrm{~m}$ above sea level and just $20 \mathrm{~m}$ inland from the shoreline so as to be visible from the sea ice. Its builders would have known that its location on the coast approximately $10 \mathrm{~km}$ from Cape Southwest would make it easy to relocate either by themselves or by someone else who would be told of its location. On the basis of the information currently available, we conclude that the cache probably consisted of boxes and bags of items, all perhaps wrapped together in canvas that was in turn thoroughly tied in ropes. This would account for the differing kinds of canvas and rope that were found. The absence of any large rocks in the area would explain why the cache was not further protected.

We know that the RCMP explored the vicinity of Cape Southwest during their search in 1932 (Barr, 1993, 2004), and Barr (2004:168) notes that the search parties passed the location of the cache a total of seven times. We believe that the cache went unnoticed because it had already been torn open by bears and its contents scattered. In addition, it seems reasonable to assume that the site would have been snow-covered in April and May. But even if the site was exposed, the majority of the finds, especially the larger items, might have been missed because they were situated on the inland slope of the beach ridge, where they would have been just out of sight of anyone traveling on the sea ice. The distribution of several of the larger and heavier items, including the transit and wooden box, suggest that over the years the items were gradually transported downslope and into a shallow gully leading to the shore. Some lighter items, such as the items of clothing and fragments of canvas, appear to have been blown some distance from the cache.

Assuming that this set of objects does indeed derive from a cache and not from the kind of catastrophe envisaged by Brooks et al. (2004), the particular items that were included provide some insight into the state of the expedition at the time the cache was constructed. We believe the answer to Brooks et al.'s question about why anyone would abandon valuable equipment and samples is that the explorers did not see themselves as abandoning these items - they intended that someday they themselves or someone else would return and retrieve them. But for these items to be cached, it must nonetheless have been vitally important to lighten the sledge as much as possible, indicating that the expedition was experiencing some significant difficulty. The presence of the cup and plate and perhaps the presence of the items of clothing could point to the most plausible explanation for why the expedition found it necessary to cache all these items. If we assume that one plate and cup would have been brought for each of the three expedition members, the presence of this single set may indicate that one person had already died. If that was the case, and if the two survivors had few dogs and were helping to pull the sledge themselves, then lightening 
the sledge would have been a priority. However, the fact that they did not abandon heavy items such as the geological samples or the transit out on the sea ice but instead transported them to the vicinity of Cape Southwest, a prominent and wellknown landmark, and then carefully packaged the items into a cache, suggests that they did not consider themselves in an immediately desperate situation.

Given this interpretation, it seems likely that the German Arctic Expedition, perhaps reduced to two people, would have proceeded east from the cache near Cape Southwest with the intention of traveling around the south coast of Axel Heiberg Island and up Eureka Sound in order to get back to Bache Peninsula. Brooks et al. (2004:228) speculate that "it is unlikely that any subsequent camp will be found" because those coastlines have been very well surveyed in the course of various scientific projects, but no one has reported any finds attributable to the German Arctic Expedition. However, it is nonetheless possible that further finds may be made-or may already have been made, but not recognized as important. We encourage anyone who has seen historic artifacts or sites in this region to report these discoveries to the Government of Nunavut so that they can be investigated and this fascinating and tragic episode in Nunavut's history can be further documented and understood.

\section{ACKNOWLEDGEMENTS}

This fieldwork was conducted under Nunavut Territory Archaeologist Permit No. 04-01A. Transportation and logistical support in the field were provided by the Polar Continental Shelf
Project. The authors wish to acknowledge the assistance of Tara Grant (Assistant Curator, Archaeology, Canadian Conservation Institute), who provided conservation advice and services, and John England, who provided additional information concerning the original discovery of the SbJk-1 site. Thanks are also extended to filmmakers Ole Gjerstad of Words \& Pictures Videos and Henry Naulaq of the Inuit Broadcasting Corporation. The authors are of course responsible for all errors of fact or interpretation.

\section{REFERENCES}

BARR, W. 1993. The career and disappearance of Hans K.E. Krüger, Arctic geologist, 1886-1930. Polar Record 29: 277-304.

- 2004. Red serge and polar bear pants: The biography of Harry Stallworthy, RCMP. Edmonton: University of Alberta Press.

BROOKS, R.C., ENGLAND, J.H., DYKE, A.S., and SAVELLE, J.M. 2004. Krüger's final camp in Arctic Canada? Arctic 57(2):225-229.

DE LAGUNA, F. 1997. The fate of Krueger's expedition. In: Gilberg, R., and Gulløv, H.C., eds. Fifty years of Arctic research: Anthropological studies from Greenland to Siberia. Copenhagen: Department of Ethnography, National Museum of Denmark. 93-98.

JOY, A.H. 1931. Letter to the Commissioner, RCMP, 25 September 1931. NAC RG 18, Acc. No. 85-86/048, File G 804-9, Pt. 1:73.

KOBALENKO, J. 2002: The horizontal Everest: Extreme journeys on Ellesmere Island. New York: Soho.

OSCZEVSKI, R.J. 1994. The disappearance of Hans Krüger. Polar Record 30:157-158. 